\title{
Color pattern variation in Trichomycterus iheringi (Eigenmann, 1917) (Siluriformes: Trichomycteridae) from rio Itatinga and rio Claro, São Paulo, Brazil
}

\author{
Cristiane C. F. da Silva ${ }^{1}$, Sara Lívia S. Fernandes da Matta ${ }^{1}$, Alexandre W. S. Hilsdorf ${ }^{1}$, \\ Francisco Langeani ${ }^{2}$ and Alexandre P. Marceniuk ${ }^{1}$
}

Color pattern is recognized as an important characteristic for diagnosing Trichomycterus species and for elucidating their relationships. An analysis based on morphological and molecular data confirms the existence of a single species of Trichomycterus in the rio Itatinga, a costal river drainage on the escarpment of the Serra do Mar and the rio Claro on the upper course of the rio Tietê. The only species found, Trichomycterus iheringi, shows two clearly distinct patterns of body pigmentation and intermediate color patterns related to body size and microhabitat preference.

O padrão de coloração é reconhecido como uma característica importante para a diagnose das espécies do gênero Trichomycterus e no reconhecimento de suas relações de parentesco. A análise baseada em dados morfológicos e moleculares confirma a existência de uma única espécie de Trichomycterus no rio Itatinga, drenagem litorânea da Serra do Mar e no rio Claro, curso superior do rio Tietê. A única espécie do gênero encontrada, Trichomycterus iheringi, apresenta dois padrões de pigmentação do corpo bastante distintos e padrões de coloração intermediários relacionados ao tamanho corporal e ao micro-habitat.

Key words: Body pigmentation, Cytocrome $c$ oxidase, Conspecificity, Southeast Brazil.

\section{Introduction}

The family Trichomycteridae is a monophyletic group of small-sized catfishes, with approximately 200 species, arranged in 41 genera and eight subfamilies (Baskin, 1973; de Pinna, 1998; Wosiacki, 2005). Trichomycteridae is mostly known for the parasitic habits of the Stegophilinae and Vandellinae species, although the majority of forms are non-parasitic, feeding on aquatic or allochthonous invertebrates (de Pinna, 1988). The subfamily Trichomycterinae is the largest group among the non-parasitic component and clearly a polyphyletic group (Baskin, 1973; de Pinna, 1989; Costa \& Bockmann, 1993). The subfamily includes five monotypic genera and the polyphyletic genus Trichomycterus Valenciennes, 1832 (de Pinna 1989; de Pinna \& Wosiacki, 2003; Sato, 2007).

Trichomycterus is a diverse assemblage with about 100 species ranging throughout Central and South America on both sides of the Andes (de Pinna \& Wosiacki, 2003). Most members inhabit headwaters and small courses of cold clear water streams with stony beds and strong currents (de Pinna, 1998). The species generally have a restricted geographic distribution and display a pronounced level of endemism (Costa, 1992; de Pinna, 1992b). The diversity of the genus is still poorly known and species-level identification is problematic due to the overwhelming number of and poorly characterized species, as well as scarce information available on nominal species. The majority of them can be only diagnosed by the combination of characteristics, and many studies consider the redescription of the poorly known species essential to a better taxonomic knowledge of the genus (Arratia, 1998; Fernández, 2000). Approximately 33 species of Trichomycterus have been described for the upper

\footnotetext{
${ }^{1}$ Universidade de Mogi das Cruzes, Núcleo Integrado de Biotecnologia, Laboratório de Genética de Organismos Aquáticos e Aquicultura. CP 411,08701-970 Mogi das Cruzes, SP, Brazil. a_marceniuk@hotmail.com

${ }^{2}$ UNESP, Universidade Estadual Paulista, Laboratório de Ictiologia, Departamento de Zoologia e Botânica. Rua Cristóvão Colombo, 2265 , 15054-000 São José do Rio Preto, SP, Brazil.
} 
rio Paraná, upper rio São Francisco, and coastal drainages of southeastern Brazil, which also contain many undescribed species (Costa, 1992; Alencar \& Costa, 2004). The color pattern is recognized as a very distinctive and important characteristic for diagnosing Trichomycterus species (Alencar \& Costa, 2004, 2006; Bockmann et al., 2004; Lima \& Costa, 2004; Wosiacki, 2004, 2005; Wosiaki \& de Pinna, 2008b; Castellanos-Morales, 2008) and also for establishing relationship among species (Barbosa \& Costa, 2003; Bockmann \& Sazima, 2004; Bockmann et al., 2004; Alencar \& Costa, 2006; Wosiack \& de Pinna, 2008a). In spite of this, Arratia et al. (1978) has described a remarkable intraspecific variation of body coloration for Trichomycterus mendozensis Arratia, Chang, Menu-Marque \& Rojas, 1978 (= Silvinichthys mendozensis in Arratia, 1998), CastellanosMorales (2007) shows different adult and young color patterns for T. santanderensis Castellanos-Morales, 2007, a troglomorphic catfish, whereas Lima et al. (2008) describe a conspicuous color pattern variation for T. caipora Lima, Lazzarotto \& Costa, 2008.

Trichomycterus iheringi was recently redescribed by Wosiacki (2005) based only on the type-series. In the present study, we describe newly collected specimens from near the type locality, showing color variation not formerly described, in which two distinct color patterns and intermediate transitional stages related to ontogenetic variation and microhabitat preference are present. We also revise and discuss the variation of other morphological characters interpreted as important for diagnosing $T$. iheringi.

\section{Material and Methods}

The specimens examined were collected in the rio Itatinga and tributaries located on the escarpment of the Serra do Mar in the Parque das Neblinas, a Natural Patrimony Private Reserve, and in the rio Claro on the upper course of the rio Tietê in the Paulistano plateau, the first in the Bertioga municipality and the second in the Salesópolis municipality, both in São Paulo State. The specimens were collected in regions with shallow stretches, fast rapids and pools with calm waters, alternating river beds composed of sand or stone and cold water (around $15^{\circ} \mathrm{C}$ ) that was totally transparent. Thirty-two specimens, ranging from 14.2 to $110.9 \mathrm{~mm} \mathrm{SL}$, were collected together with field observations concerning their behavior. Additionally, we examined another twelve specimens, ranging from 39.9 to $133.9 \mathrm{~mm} \mathrm{SL}$, from the collection of the Museu de Zoologia da Universidade de São Paulo (MZUSP).

Methodology and terminology for measurements and counts follow de Pinna (1992a, 1992b) and Bockmann \& Sazima (2004). The conspecificity of examined specimens was tested by sequencing the mitochondrial cytocrome $c$ oxidase subunit I (COX1) gene (Ward et al., 2005; Steinke et al., 2009). DNA was isolated from 12 specimens with distinct length and color pattern, according to Taggart et al. (1992). The DNA integrity and concentration were evaluated using agarose gel and spectrophotometer (NanoDrop ${ }^{\circledR}$ ND-1000). The COX1 region was amplified using the primers L6252 (5'-AAG GCG GGG AAA GCC CCG GCA-3') and H7271 ( 5'-TCC TAT GTA GCC GAA TGG TTC TTT T-3') (Cláudio Oliveira, pers. comm.) using the following conditions: a master mix of 10 pmol of each primer, $2.5 \mathrm{mM} \mathrm{MgCl}, 2.5 \mathrm{mM}$ of deoxynucleotide triphosphate, 1 unit of Taq DNA polymerase, 50-100 ng of total DNA, $2.5 \mu$ l of 10x Taq buffer and a volume of water to bring the final volume to $50 \mu$. Cycling conditions were as follows: hot start denaturation step at $94^{\circ} \mathrm{C}$ for $3 \mathrm{~min}$ followed by 35 cycles of denaturation at $94^{\circ} \mathrm{C}$ for $1 \mathrm{~min}$, annealing at $59.8^{\circ} \mathrm{C}$ for $45 \mathrm{~s}$ and extension at $72^{\circ} \mathrm{C}$ for 2 min with a final 10 min extension step at $72^{\circ} \mathrm{C}$. PCR products were visualized in $1 \%$ agarose gel and purified using the E.Z.N.A. ${ }^{\circledR}$ System (Omega Bio-Tek, Inc.). The purified PCR products were sequenced with the BigDye ${ }^{\mathrm{TM}}$ Terminator Cycle Sequencing kit (PE Applied Biosystems) according to the protocols provided by the manufacturer. Electrophoresis of the purified samples was performed in an ABI Prism 3100 DNA Sequencer (Perkin Elmer).

The sequences were aligned with the software ClustalW (Thompson et al., 1994) and checked manually. The consensus sequences were obtained by BIOEDIT Sequence Alignment Editor 7.0.9 (Hall, 1999). In silico sequences nucleotide divergence was implemented with MEGA 4.0 (Kumar et al., 2001) with 3.000 bootstrap replicates using Kimura-2parameter genetic distance. GenBank accession numbers of sequences are listed in Table 1. Trichomycterus iheringi tissue 10840 (LBP 1296), T. auroguttatus tissue 10250 (LBP 1014), and T. paolence tissue 9874 (LBP 945) sequences were obtained by Sato (2007).

Acronyms and abbreviations used are: DZSJRP, Departamento de Zoologia e Botânica, Universidade Estadual Paulista, São José do Rio Preto (SP); LPB, Laboratório de Biologia e Genética de Peixes, Universidade Estadual Paulista, Botucatu (SP); MZUSP, Museu de Zoologia da Universidade de São Paulo (SP).

Material examined. Trichomycterus iheringi: Brazil, São Paulo State: DZSJRP 12333 (tissue sample ID 22, 43, 90), 3, 46.4-87.2 mm SL, Bertioga, Parque das Neblinas, rio Itatinga, stony river bed. DZSJRP 12334 (tissue sample ID 26, 59, 66), 17, 14.2-51.2 mm

Table 1. List of tissue samples and GenBank Accession numbers.

\begin{tabular}{lccc}
\hline \multicolumn{1}{c}{ Species } & Catalog N & Tissue N $^{\mathrm{o}}$ & $\begin{array}{c}\text { GenBank } \\
\text { Accession Nos. }\end{array}$ \\
\hline Trichomycterus iheringi & DZSJRP 12335 & ID 67 & GU350775 \\
Trichomycterus iheringi & DZSJRP 12335 & ID 12 & GU350776 \\
Trichomycterus iheringi & DZSJRP 12334 & ID 26 & GU350777 \\
Trichomycterus iheringi & DZSJRP 12334 & ID 59 & GU350778 \\
Trichomycterus iheringi & DZSJRP 12334 & ID 66 & GU350779 \\
Trichomycterus iheringi & DZSJRP 12333 & ID 22 & GU350780 \\
Trichomycterus iheringi & DZSJRP 12333 & ID 43 & GU350781 \\
Trichomycterus iheringi & DZSJRP 12333 & ID 90 & GU350782 \\
Trichomycterus iheringi & DZSJRP 12337 & ID 08 & GU350783 \\
Trichomycterus iheringi & DZSJRP 12337 & ID 49 & GU350784 \\
Trichomycterus iheringi & DZSJRP 12338 & ID 80 & GU350785 \\
Trichomycterus iheringi & DZSJRP 12335 & ID 47 & GU350786 \\
\hline
\end{tabular}


SL, Bertioga, Parque das Neblinas, rio Itatinga, sandy river bed. DZSJRP 12335 (tissue sample ID 12, 47, 67), 4, 41.6-52.4 mm SL, Bertioga, Parque das Neblinas, rio Itatinga, sandy river bed. DZSJRP 12336, 1, $72.1 \mathrm{~mm}$ SL, Bertioga, Parque das Neblinas, tributary of the rio Itatinga, $2-3 \mathrm{~km}$ before the concrete bridge, stony river bed. DZSJRP 12337 (tissue sample ID 08, 49), 6, 29.1-58.0 mm SL, Salesópolis, tributary of the rio Claro, stony river bed. DZSJRP 12338 (tissue sample ID 80), 1, 100.9 mm SL, Salesópolis, rio Claro, before concrete bridge, stony river bed. MZUSP 36635, 12 of 145, 50.1-133.9 mm SL, Salesópolis, tributaries of the rio Claro, water main of SABESP, $23^{\circ} 32^{\prime}$ 'S, $45^{\circ} 51^{\prime}$ 'W. MZUSP 85903, 1, 96.2 $\mathrm{mm}$ SL, Itapecerica da Serra, Embu-Guaçu, rio Lavras, tributary of the rio Tietê, 2354'46"'S 46055'12"W. MZUSP 87720, 2 of 6, 39.8$67.7 \mathrm{~mm}$ SL, Bertioga, Parque das Neblinas, tributary of the rio Itatinga. LBP 1296 (tissue sample 10840), 1, Botucatu, rio Alambari, $22^{\circ} 56^{\prime} 08^{\prime \prime} \mathrm{S} 48^{\circ} 19^{\prime} 15^{\prime \prime} \mathrm{W}$.

Comparative material examined. Brazil: Trichomycterus auroguttatus. LBP 1014 (tissue sample 10250), 1, Minas Gerais, rio Chopotó, tributary of the rio Doce, $21^{\circ} 08^{\prime}$ '94.7'S 43²3'97.3'W. LBP 1016 (tissue sample 10249), 1, Minas Gerais, Caranaíba and Capela Nova, rio Piranga, tributary of the rio Doce, 205' 17.1 'S 4342'33.1'W. Trichomycterus paolence. LBP 945 (sample tissue 9874), 1, São Paulo, Itatinga, ribeirão da Quinta, 2306'30.7'S 48³0'18.1"W. Trichomycterus triguttatum. MZUSP 44536, 15, 48.7-80.7 mm SL, São Paulo, Silveiras, tributary of the Bocaína, stream of Altão, $22^{\circ} 44^{\prime}$ 'S $44^{\circ} 51^{\prime} \mathrm{W}$. Trichomycterus sp. MZUSP 86988, 3, 30.4-44.4 mm SL, São Paulo, Santo André, rio Pardo, tributary of the rio Grande, 2346'03"S 46¹9'17.9'W. MZUSP 24548, 6, 29.7-77.3 mm SL, São Paulo, Analândia Grande, stream of the ranch Candinha, $22^{\circ} 08^{\prime}$ 'S $47^{\circ} 40^{\prime} \mathrm{W}$. MZUSP 47596, 5, 60.4$78.3 \mathrm{~mm}$ SL, São Paulo, Pindamonhangaba, tributary of the Ribeirão Grande, 22 ${ }^{\circ} 56^{\prime} S$ 4 $45^{\circ} 28^{\prime} \mathrm{W}$. MZUSP 40236, 2, São Paulo, rio Corumbataí, waterfall of Analândia, $22^{\circ} 13^{\prime} \mathrm{S} 47^{\circ} 37^{\prime} \mathrm{W}$.

\section{Results}

\section{Molecular evidence of the conspecificity of specimens with different color patterns}

An average of 409 base pairs (bp) of COX1 in 12 Trichomycterus iheringi specimens from rio Itatinga and rio Claro were sequenced. The transition/transversion rate ratios were 6.402 for purines and 5.885 for pyrimidines. The overall transition/transversion bias was $\mathrm{R}=2.983$. The average nucleotide frequencies were $\mathrm{A}=24.2 \%, \mathrm{~T}=29.4 \%, \mathrm{C}=28.3 \%$ and $\mathrm{G}=18.1 \%$. COX 1 sequences of all 13 specimens of $T$. iheringi (including 1 specimen from Botucatu, rio Alambari, LBP 1296) were either identical or very similar. The average Kimura-2-parameter [K2P] differences among them was $0.53 \%$ ranging from 0 to $1 \%$ which is lower than the $5.73 \%$ genetic divergence of the other recognized Trichomycterus auroguttatus Costa, 1992 and T.paolence (Eigenmann, 1917) species. The neighbor-joining (NJ) tree showed shallow intraspecimen divergences among specimens with different color patterns (Fig. 1). The mean of COX1 genetic divergence sequences between Trichomycterus specimens with different color patterns was lower than the $2 \%$ expected for different species (Hebert et al., 2003). This indicates the conspecificity of the specimens of Trichomycterus iheringi with different color patterns, including those caught in different river drainages.

\section{Taxonomic identity of specimens examined}

Trichomycterus iheringi was described by Eigenmann (1917) based on specimens collected in Santos, on the coastal area of São Paulo State, and in the headwaters of rio Tietê in the upper rio Paraná basin (holotype CAS 64585,

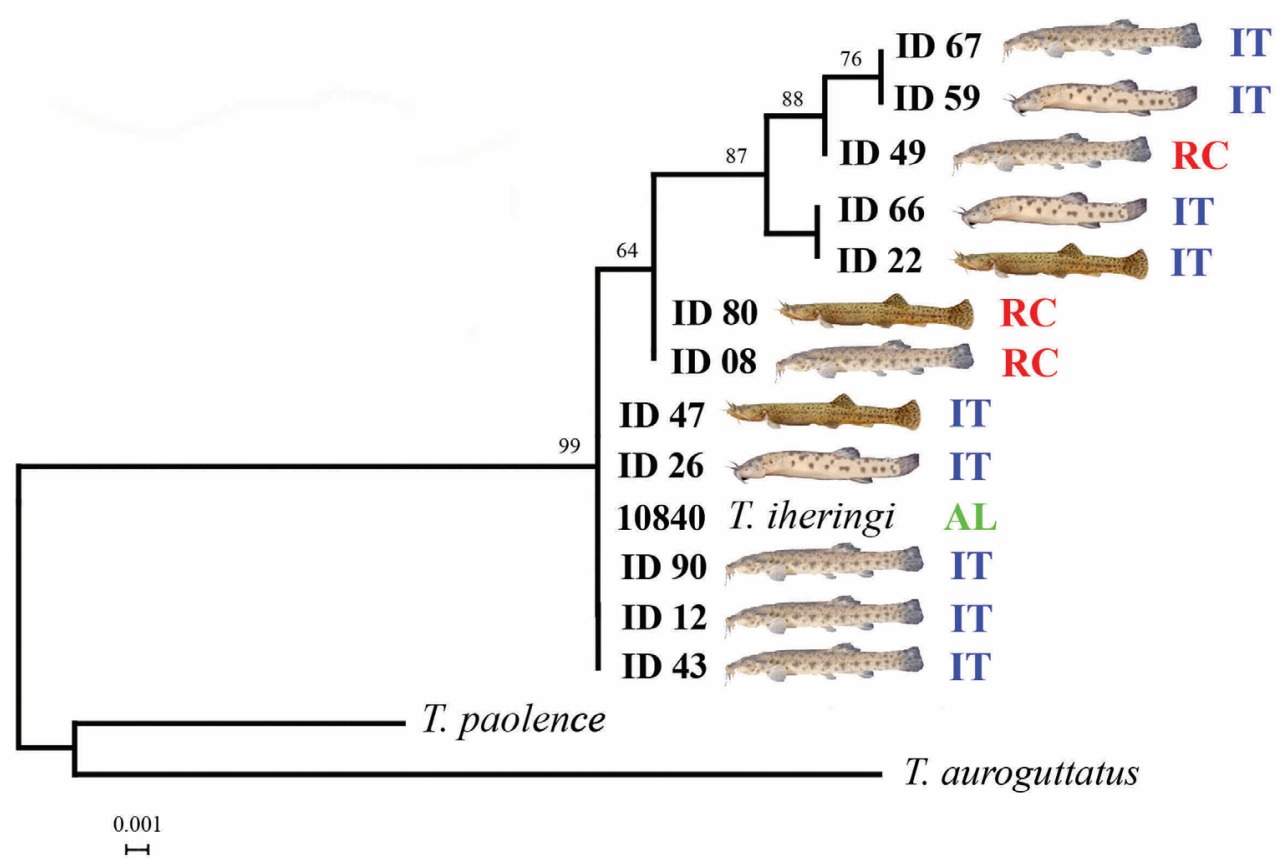

Fig. 1. K2P distance neighbour-joining tree of COX1 sequences from 15 specimens of Trichomycterus species. Bootstrap values greater than 50 shown. Specimen access numbers for the GeneBank given in Table 1. Abbreviations: AL - rio Alambari; IT - rio Itatinga; $\mathrm{RC}$ - rio Claro. 
paratypes CAS 64586 and FMNH 58074). The species was recently redescribed by Wosiacki (2005), who has not found uniquely derived features to diagnose the species and presented a new diagnosis based on the following combination of characters: 9 to 10 dorsal-fin branched rays; first pectoral-fin ray not prolonged as a filament; i,7 pectoralfin rays; caudal-fin margin rounded; two 56 pores paired at the interorbital space; pelvic-fin margin distance from the urogenital opening equal to half of its length; and adult specimens with uniform light tan color pattern with numerous, poorly defined small spots irregularly distributed on the body.

In the present study, the specimens examined were recognized as $T$. iheringi and distinguished from its congeners from south and southeastern Brazil by the same distribution of the type-specimen and by possessing the first pectoral-fin ray not prolonged as a filament; i,7 pectoral-fin rays (Table 2); caudal-fin margin rounded; two s6 pores paired at the interorbital space; and adult specimens with uniform grayish brown color, with numerous poorly defined small spots irregularly distributed on the body (Fig. 2).

\section{Variation of body pigmentation}

Trichomycterus iheringi specimens show two very distinct well-defined patterns of body pigmentation, and intermediate color patterns clearly related to size and microhabitat preference. The first color pattern is observed in smaller juvenile specimens, between 14.2 to $51.2 \mathrm{~mm} \mathrm{SL} \mathrm{(Fig.} \mathrm{3a,} \mathrm{b),}$ invariably captured partially or totally buried in clear sand, with same tonality as trunk background color of specimens. The color pattern is characterized by head uniform gray dorsally, gradually lighter laterally, and latero-ventrally with same ground color as trunk. Nasal barbel dark, with same color as dorsal portion of head, maxillary and rictal barbels unpigmented from base to half of their length and slightly pigmented on distal half. Ground color of trunk and caudal peduncle light cream to pale yellow (likely the color of river bottom), with two regular longitudinal rows, each with 8 to 13 well-defined dark brown blotches, larger than eye-diameter, formed of densely grouped chromatophores, one along dorsal region and other, most conspicuous, along midlateral region. Sometimes with poorly defined small spots loosely distributed between these two regular longitudinal rows. Pectoral and pelvic fins unpigmented, dorsal and anal fins unpigmented from base to half of their length, with few small spots on

Table 2. Meristic frequencies of Trichomycterus iheringi from rio Itatinga and rio Claro.

\begin{tabular}{lccc}
\hline \multicolumn{1}{c}{ Dorsal-fin rays } & ii, & ii, 8 & ii,9 \\
\hline $\begin{array}{l}\text { rio Itatinga } \\
\text { rio Claro }\end{array}$ & 1 & 18 & 8 \\
\multicolumn{1}{c}{ Pectoral-fin rays } & $\mathrm{i}, 6$ & $\mathrm{i}, 7$ & 5 \\
\hline \begin{tabular}{l}
\multicolumn{1}{c}{ Pelvic-fin rays } \\
rio Itatinga \\
rio Claro
\end{tabular} & 1 & 26 & \\
\hline \multicolumn{1}{c}{ Anal-fin rays } & $\mathrm{i}, 4$ & & \\
\hline $\begin{array}{l}\text { rio Itatinga } \\
\text { rio Claro }\end{array}$ & 27 & & \\
\hline \multicolumn{1}{c}{ Caudal-fin rays } & 17 & & $\mathrm{ii}, 5$ \\
\hline $\begin{array}{l}\text { rio Itatinga } \\
\text { rio Claro }\end{array}$ & $\mathrm{ii}, 3$ & $\mathrm{ii}, 4$ & 24 \\
\hline \multicolumn{1}{c}{1} & 2 & 1 \\
\hline $\begin{array}{l}\text { rio Itatinga } \\
\text { rio Claro }\end{array}$ & 1 & 15 & $\mathrm{i}, 12, \mathrm{i}$ \\
\hline
\end{tabular}

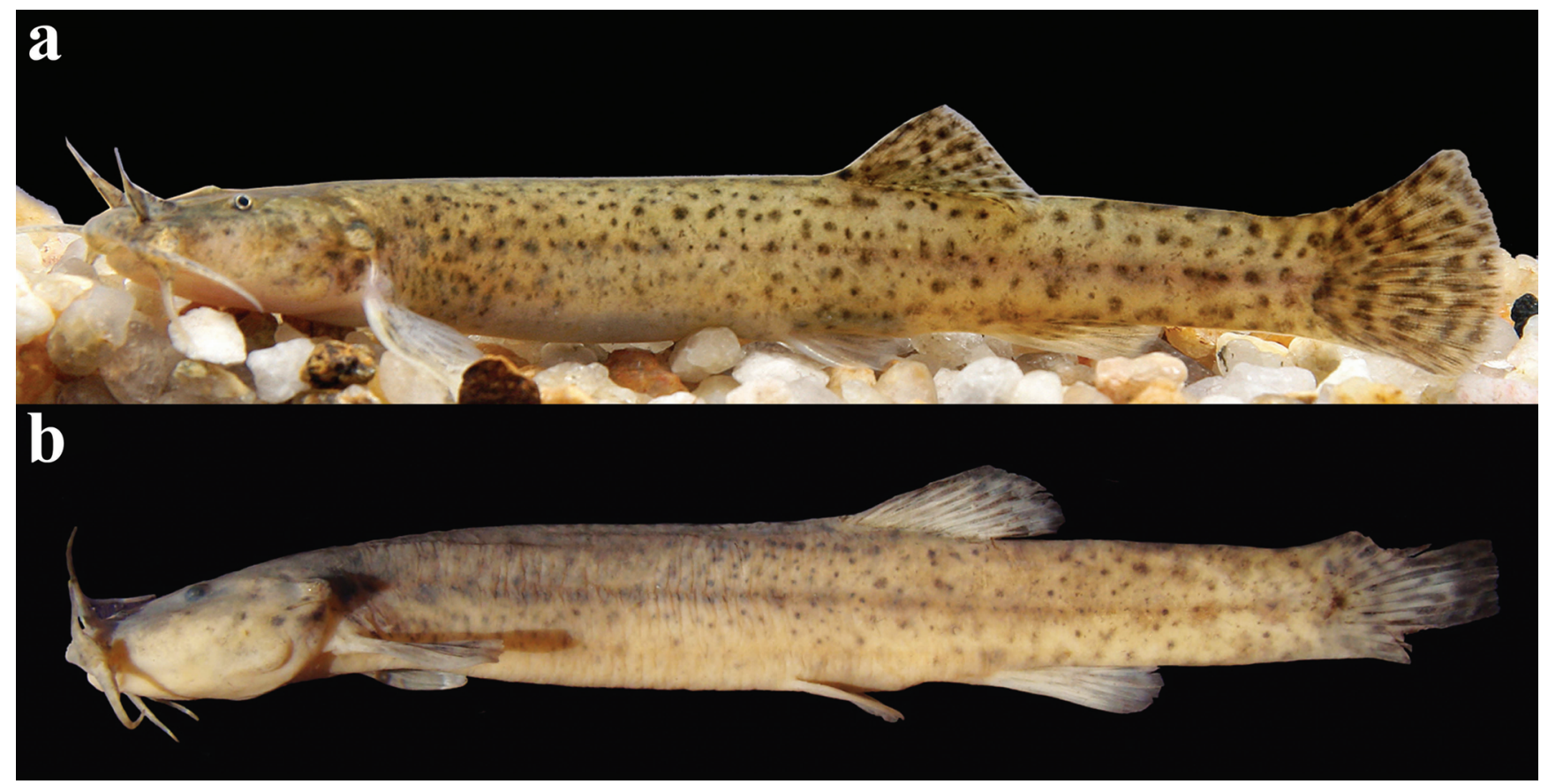

Fig. 2. Characteristic coloration of adult Trichomycterus iheringi (DZSJRP 12333), $87.2 \mathrm{~mm}$ SL, rio Itatinga. (a) Photographed in aquarium after collection; (b) preserved. 

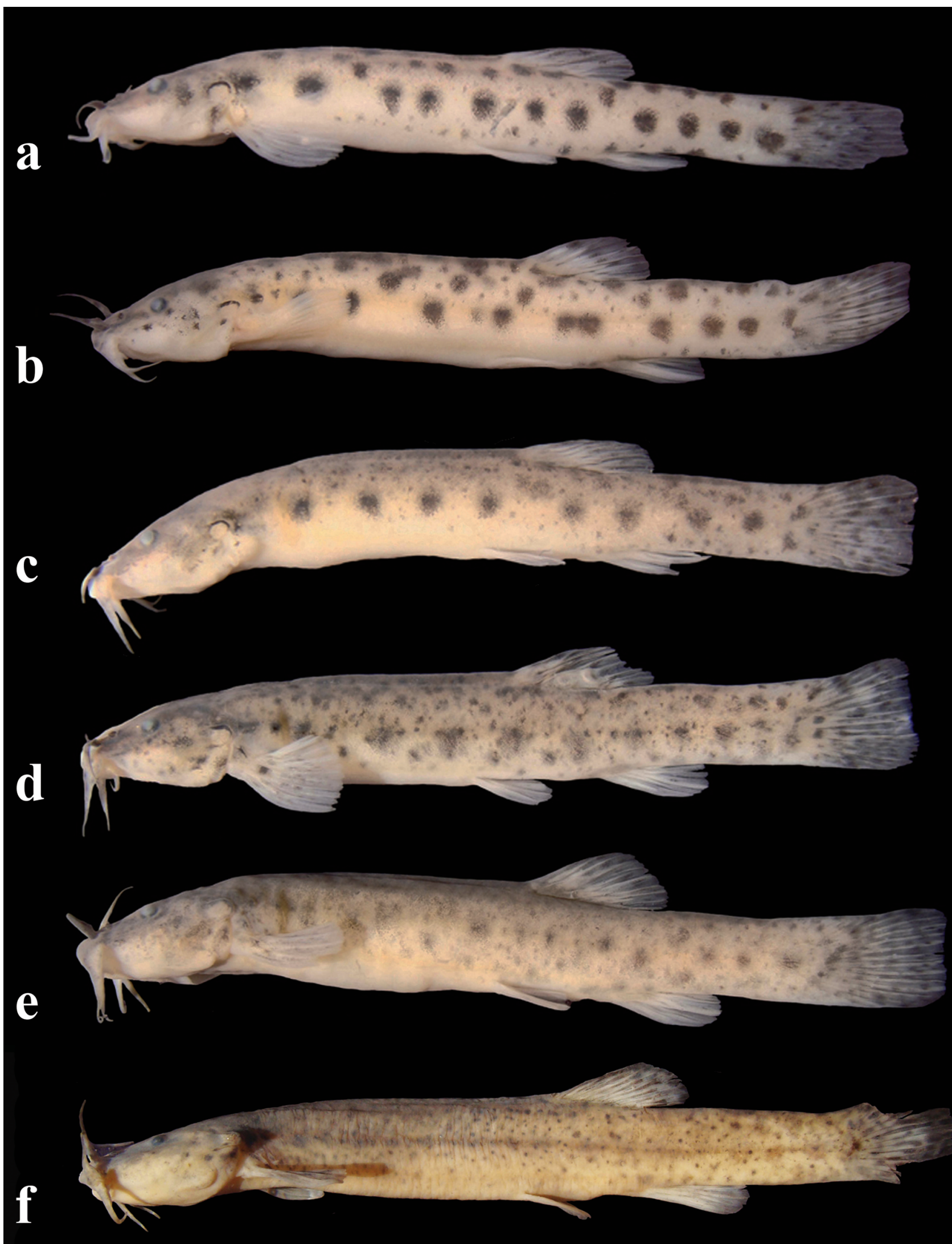

Fig. 3. Color variation in Trichomycterus iheringi. (a) ID-66; 30.9 mm SL (DZSJRP 12334); (b) ID-26; 48.7 mm SL (DZSJRP 12334); (c) ID-59; 36.7 mm SL (DZSJRP 12334); (d) ID-12; 41.6 mm SL (DZSJRP 12335); (e) ID-67; 49.8 mm SL (DZSJRP 12335); (f) ID-22; $87.2 \mathrm{~mm}$ SL (DZSJRP 12333). 
distal half, caudal fin with small spots from base to tip.

A second, very distinct color pattern was observed in larger adult specimens, between 52.4 to $133.9 \mathrm{~mm}$ SL (Figs. 2 and $3 \mathrm{f}$ ), always captured in areas with river bottom formed by with variously sized dark stones. The pattern is characterized by head dark dorsally, gradually lighter ventrally; nasal barbel dark as dorsal portion of head, maxillary and rictal barbels slightly pigmented, with same coloration as trunk. Trunk ground color uniformly grayish brown, with numerous small spots, as large as eye-diameter or smaller, irregularly distributed on the dorsal and lateral surface of head, trunk and caudal peduncle, gradually less numerous ventrally. Pectoral and pelvic fins unpigmented, dorsal and caudal fins with same coloration as trunk and anal fin relatively lighter, with few spots.

Specimens with intermediate sizes, between 36.7 to 68.9 mm SL (Fig. 3c, d, e), with transitional phases of body coloration were captured in the same areas as the larger adults, generally associated with those. Well-defined dark brown large blotches, larger than eye-diameter along dorsal region of trunk are absent, but those along midlateral region are always present but variable. Blotches in some specimens are quite conspicuous and formed by densely grouped chromatophores (Fig. 3c), in other specimens are less conspicuous, formed by loosely arranged chromatophores (Fig. 3d, e). These specimens with intermediate sizes begin to show small spots, as large as eye-diameter or smaller, irregularly distributed on dorsal and lateral surfaces of head, trunk and caudal peduncle, which are also quite variable, ranging from few and inconspicuous spots along lateral region of trunk (Fig. 3c, e), to quite numerous and conspicuous (Fig. 3d). Head, trunk, caudal peduncle, nasal, maxillary and rectal barbels, and fins with same ground color as described for juvenile specimens.

\section{Discussion}

Many authors have recognized color pattern as a very distinctive and important characteristic to distinguish species of Trichomycterus (Alencar \& Costa, 2004, 2006; Bockmann, et al., 2004; Lima \& Costa, 2004; Wosiacki, 2004, 2005; Wosiaki \& de Pinna. 2008a,b; Castellanos-Morales, 2008). Only Arratia et al. (1978) and Lima et al. (2008) have described a remarkable intraspecific variation of body pigmentation for Silvinichthys mendozensis and Trichomycterus caipora, although Bockmann \& Sazima (2004) considered intraspecific variation of body pigmentation in $S$. mendozensis a highly unusual condition within Trichomycteridae and considered the body coloration pattern highly conserved in known species based on inspections of ontogenetic series of several Trichomycterus species (see material comparative examined by Bockmann \& Sazima, 2004).

Our results have shown that this is not the case for $T$. iheringi. Wosiacki (2005) redescribed $T$. iheringi based only on adult specimens, while variations exhibited by juvenile specimens led Serra et al. (2007) to consider the Trichomycterus from the rio Itatinga as a species with undefined taxonomic status and possibly being an undescribed species, and not juveniles of T. iheringi as proposed here based on analysis of a larger series. Other comparative material examined (see in comparative material examined, MZUSP 44536, MZUSP 47596, and MZUSP 86988) also show similar color pattern variation.

Besides color pattern variation, some other diagnostic characteristics proposed by Wosiacki (2005) for T. iheringi were also highly variable when large series of variously sized specimens were examined, and therefore not useful for diagnosis. A pelvic-fin margin distance to the urogenital opening equal to half of the fin length was observed in specimens between 41.6 to $133.9 \mathrm{~mm} \mathrm{SL} \mathrm{(19} \mathrm{specimens),}$ whereas those between 14.2 to $58.0 \mathrm{~mm} \mathrm{SL}$ ( 25 specimens) have the pelvic-fin margin contacting the urogenital opening. Wosiacki (2005) only examined the type-specimens with 117.6 to $139.6 \mathrm{~mm} \mathrm{SL}$, with pelvic-fin margin distance to the urogenital opening equal to half of the fin length. Dorsal-fin rays also show a greater variation, with ii, 7 ( 1 specimen), ii, 8 (29 specimens), or ii,9 (13 specimens; Table 2), contrarily to the range ii-iii,9-10 described by Wosiacki (2005).

Additionally, morphological differences help to partially distinguish the rio Itatinga and rio Claro specimens. The specimens from the rio Itatinga show relatively longer pectoral-fin base length (4.3-6.6\% SL) than those from rio Claro (3.5-4.5\% SL) (Table 3, Fig. 4), and relatively more analfin rays ii, 5 (24 specimens, $88.8 \%$ ), than those from rio Claro ii,4 (15 specimens, $88.2 \%$; Table 2).

Table 3. Morphometric data of Trichomycterus iheringi, from rio Itatinga and rio Claro.

\begin{tabular}{lcccccc}
\hline & \multicolumn{3}{c}{ Rio Itatinga } & \multicolumn{2}{c}{ Rio Claro } \\
\cline { 2 - 7 } & $\mathrm{N}$ & Mean & Min-Max & $\mathrm{N}$ & Mean & Min-Max \\
\hline Standard length (mm) & 27 & & $14.2-87.2$ & 17 & & $29.1-133.9$ \\
\multicolumn{1}{l}{ Percents of standard length } & & & & & \\
Head length & 27 & 24.1 & $21.0-28.6$ & 17 & 22.1 & $20.6-24.1$ \\
Predorsal length & 26 & 62.6 & $59.5-66.4$ & 17 & 60.9 & $58.4-62.9$ \\
Prepelvic length & 27 & 54.8 & $45.2-58.0$ & 17 & 54.9 & $50.1-58.5$ \\
Preanal length & 27 & 74.7 & $70.6-82.7$ & 17 & 72.8 & $69.1-74.3$ \\
Pectoral girdle width & 19 & 12.5 & $10.9-14.3$ & 16 & 13.7 & $12.1-14.9$ \\
Trunk length & 19 & 78.7 & $74.6-82.1$ & 14 & 80.7 & $78.0-82.8$ \\
Pectoral-fin base length & 27 & 5.5 & $4.3-6.6$ & 17 & 3.8 & $3.5-4.5$ \\
Pectoral-fin length & 18 & 13.7 & $10.3-17.2$ & 16 & 11.8 & $9.5-14.4$ \\
Pelvic-fin base length & 27 & 3.7 & $2.5-5.0$ & 17 & 2.8 & $2.4-3.5$ \\
Pelvic-fin length & 19 & 9.8 & $8.0-11.3$ & 16 & 8.9 & $7.3-10.6$ \\
Distance pelvic-fin to anus & 24 & 11.2 & $10.1-12.7$ & 17 & 10.5 & $8.8-11.3$ \\
Caudal peduncle length & 27 & 20.6 & $17.1-23.7$ & 17 & 20.3 & $17.9-22.2$ \\
Caudal peduncle depth & 27 & 9.6 & $7.8-10.8$ & 17 & 9.8 & $7.7-11.3$ \\
Body depth & 27 & 13.5 & $10.8-16.7$ & 17 & 14.0 & $11.8-16.5$ \\
Dorsal-fin base length & 27 & 12.9 & $10.4-17.0$ & 17 & 12.8 & $11.3-15.1$ \\
Dorsal-fin length & 19 & 11.9 & $10.1-13.9$ & 15 & 11.8 & $10.2-14.6$ \\
Anal-fin base length & 27 & 8.1 & $6.5-11.9$ & 17 & 8.0 & $6.4-9.2$ \\
Anal-fin length & 18 & 11.3 & $9.1-14.6$ & 16 & 10.8 & $9.3-12.7$ \\
$\quad$ Percents of head length & & & & & & \\
Head width & 27 & 77.0 & $61.9-86.5$ & 17 & 70.8 & $62.9-77.9$ \\
Nasal barbel length & 27 & 31.7 & $16.4-45.2$ & 16 & 42.2 & $33.9-50.0$ \\
Maxillary barbel length & 24 & 36.8 & $21.4-48.9$ & 17 & 47.0 & $36.0-57.1$ \\
Rictal barbel length & 24 & 28.3 & $11.4-41.9$ & 16 & 37.3 & $27.0-44.6$ \\
Snout length & 27 & 47.0 & $43.4-54.9$ & 17 & 50.4 & $45.7-53.5$ \\
Interorbital width & 27 & 23.2 & $19.4-26.2$ & 17 & 23.5 & $19.3-26.4$ \\
Mouth width & 23 & 21.0 & $11.4-34.2$ & 16 & 32.9 & $21.8-41.1$ \\
Eye diameter & 26 & 14.7 & $9.7-19.6$ & 15 & 11.9 & $8.7-16.4$ \\
\hline
\end{tabular}




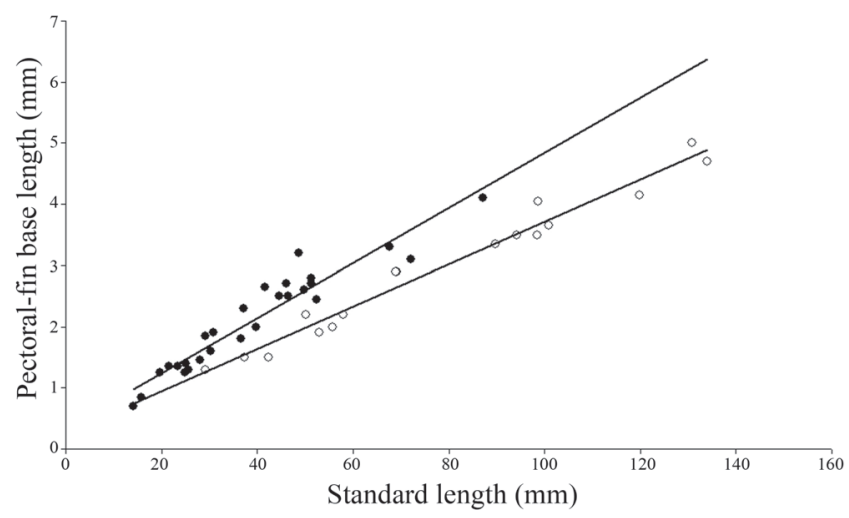

Fig. 4. Plot of standard length against pectoral-fin length for Trichomycterus iheringi from rio Itatinga (filled circle) and rio Claro (open circle).

\section{Acknowledgements}

The authors are indebted to ECOFuturo and SABESP for allowing sampling in the rio Itatinga and rio Claro. We are grateful to Osvaldo T. Oyakawa (Museu de Zoologia da Universidade de São Paulo) for providing additional specimens of Trichomycterus iheringi and other comparative species of Trichomycterus and to Claudio Oliveira and Luciana Ramos Sato for providing us specimens of T. auroguttatus, $T$. iheringi, and T. paolence. Special thanks are due to Flávio C. T. Lima (MZUSP) for critically reading the manuscript and providing valuable suggestions and comments. This work was partially supported by the Conselho Nacional de Desenvolvimento Científico e Tecnológico of the Brazilian Federal Government (CNPq) (Proc. 152782/2007-9 to APM and Proc. 306988/2008-9 to FL) and UMC/FAEP.

\section{Literature Cited}

Alencar, A. R. \& W. E. M. Costa. 2004. Description of two new species of the catfish genus Trichomycterus from southeastern Brazil (Siluriformes: Trichomycteridae). Zootaxa, 744: 1-8.

Alencar, A. R. \& W. J. E. M. Costa. 2006. Trichomycterus pauciradiatus, a new catfish species from upper rio Paraná basin, southeastern Brazil (Siluriformes: Trichomycteridae). Zootaxa, 1269: 43-49.

Arratia, G. 1998. Silvinichthys, a new genus of trichomycterid catfishes from the Argentinian Andes, with redescription the Trichomycterus nigricans. Ichthyological Exploration of Freshwaters, 9(4): 347-370.

Arratia, G., A. Chang, S. Menu-Marque \& G. Rojas. 1978. About Bullochia gen. nov., Trichomycterus mendozensis n. sp. and revision of the family Trichomycteridae (Pisces, Siluriformes). Studies on Neotropical Fauna and Environment, 13(3/4): 157-194.

Barbosa, M. A. \& W. J. E. M. Costa. 2003. Trichomycterus potschi (Siluriformes: Loricarioidei): a new trichomycterid catfish from coastal streams of southeastern Brazil. Ichthyological Exploration of Freshwaters, 14: 281-287.

Baskin, J. N. 1973. Structure and relationship of the Trichmycteridae. Unpublished Ph.D. Dissertation, University of New York, New York.
Bockmann, F. A., L. Casatti \& M. C. C. de Pinna. 2004. A new species of trichomycterid catfish from the rio Paranapanema basin, southeastern Brazil (Teleostei: Siluriformes), with comments on the phylogeny of the family. Ichthyological Exploration of Freshwaters, 15(3): 225-242.

Bockmann F. A. \& I. Sazima. 2004. Trichomycterus maracaya, a new catfish from the upper rio Paraná, southeastern Brazil (Siluriformes: Trichomycteridae), with notes on the T. brasiliensis species-complex. Neotropical Ichthyology, 2(2): 61-74.

Castellanos-Morales, C. A. 2007. Trichomycterus santanderensis: A new species of troglomorphic catfish (Siluriformes, Trichomycteridae) from Colombia. Zootaxa, 1541: 49-55.

Castellanos-Morales, C. A. 2008. Trichomycterus uisae: a new species of hypogean catfish (Siluriformes: Trichomycteridae) from the northeastern Andean Cordillera of Colombia. Neotropical Ichthyology, 6(3): 307-314.

Costa, W. J. E. M. 1992. Description de huit nouvelles espèces du genre Trichomycterus (Siluriformes: Trichomycteridae), du Brésil oriental. Revue Française de Aquariologie, 18: 101-110.

Costa, W. J. E. M. \& F. A. Bockmann. 1993. Un nouveau néoropical genre de la famille des Trichomycteridae (Siluriformes: Loricarioidei). Revue Française de Aquariologie, 20: 43-46.

Eigenmann, C. H. 1917. Descriptions of sixteen new species of Pygidiidae. Proceedings of the American Philosophical Society, 56: 690-703.

Fernández, L. A. 2000. Redescription of the teleost Trichomycterus barbouri (Eigenmann, 1911), occurrence in Argentina and comparison with related species (Ostariophysi: Siluriformes: Trichomycteridae). Studies on Neotropical Fauna and Environment, 35: 27-33.

Hall, T. A. 1999. BioEdit: a user-friendly biological sequence alignment editor and analysis program for Windows 95/98/NT. Nucleic Acids Symposium Series, 41: 95-98.

Hebert, P. D. N., S. Ratnasingham \& J. R. de Waard. 2003. Barcoding animal life: cytochrome $c$ oxidase subunit 1 divergences among closely related species. Philosophical Transactions of the Royal Society B, 270: S596-S599.

Lima, S. M. Q. \& W. J. E. M. Costa. 2004. Trichomycterus giganteus (Siluriformes: Loricarioidea: Trichomycteridae): a new catfish from the Rio Guandu basin, southeastern Brazil. Zootaxa, 761: 1-6.

Lima, S. M. Q., H. Lazzarotto \& W. J. E. M. Costa. 2008. A new species of Trichomycterus (Siluriformes: Trichomycteridae) from lagoa Feia drainage, southeastern Brazil. Neotropical Ichthyology, 6(3): 315-322.

de Pinna, M. C. C. 1988. A new genus of trichomycterid catfish (Siluroidei, Glanapteryginae), with comments on its phylogenetic relationships. Revue suisse Zoology, 1(95): 113-128.

de Pinna, M. C. C. 1989. A New Sarcoglanidine catfish, phylogeny of its subfamily, and an appraisal of the phyletic status of the Trichomycterinae (Teleostei, Trichomycteridae). American Museum Novitates, 2950: 1-39.

de Pinna, M. C. C. 1992a. A new subfamily of Trichomycteridae (Teleostei, Siluriformes), lower loricarioid relationships and a discussion on the impact of additional taxa for phylogenetic analysis. Zoological Jornal of the Linnean Society, 106: 175-229.

de Pinna, M. C. C. 1992b. Trichomycterus castroi, a new species of trichomycterid catfish from the rio Iguaçu of South Brazil (Teleostei: Siluriformes). Ichthyological Exploration of Freshwaters, 3(1): 89-95.

de Pinna, M. C. C. 1998. Phylogenetic relationships of neotropical Siluriformes (Teleostei: Ostariophysi): Historical overview and syntheses. Pp. 279-350. In: Malabarba, L. R., R. E. Reis, R. P. 
Vari, Z. M. Lucena \& C. A. S. Lucena (Eds.). Phylogeny and Classification of Neotropical Fishes. Porto Alegre, Edipucrs, 603p.

de Pinna, M. C. C. \& W. B. Wosiacki. 2003. Family Trichomycteridae. Pp. 270-290. In: Reis, R. E., S. O. Kullander \& C. J. Ferraris Jr. (Eds.). Check list of the freshwater fishes of the South and Central America. Porto Alegre, Edipucrs, 729p.

Sato, L. R. 2007. Estudo das relações filogenéticas de Trichomycteridae (Teleostei, Siluriformes) com base em evidências cromossômicas e moleculares. Unpublished Ph.D. Dissertation, Universidade Estadual Paulista, Botucatu, 87p.

Serra, J. P., F. R. Carvalho \& F. Langeani. 2007. Ichthyofauna of the rio Itatinga in the Parque das Neblinas, Bertioga, São Paulo State: composition and biogeography. Biota Neotropica, 7: 81-86.

Steinke, D., T. S. Zemlak \& P. D. N. Hebert. 2009. Barcoding Nemo: DNA-Based Identifications for the Ornamental Fish Trade, PLoS ONE 4: e6300.

Taggart, J. B., R. A. Hynes, P. A. Prodöhl \& A. Ferguson. 1992. A simplified protocol for routine total DNA isolation from salmonid fishes. Journal of Fish Biology, 40: 963-965.

Ward, R. D., T. S. Zemlak, B. H. Innes, P. R. Last \& P. D. N. Hebert. 2005. DNA barcoding Australia's fish species. Philosophical Transactions of the Royal Society B, 360: 18471857.

Wosiacki, W. B. 2004. New species of the catfish genus Trichomycterus (Siluriformes: Trichomycteridae) from the headwaters of the rio São Francisco basin, Brazil. Zootaxa, 592: $1-12$.

Wosiacki, W. B. 2005. A new species of Trichomycterus (Siluriformes: Trichomycteridae) from the south Brazil and redescription of T. iheringi (Eigenmann). Zootaxa, 1040: 49-64.

Wosiacki, W. B. \& M. C. C. de Pinna. 2008a. A new species of the neotropical catfish genus Trichomycterus (Siluriformes: Trichomycteridae) representing a new body shape for the family. Copeia, 2008(2): 273-278.

Wosiacki, W. B. \& M. C. C. de Pinna. 2008b. Trichomycterus igobi, a new catfish species from the rio Iguaçu drainage: the largest head in Trichomycteridae (Siluriformes: Trichomycteridae). Neotropical Ichthyology, 6(1): 17-23.

Accepted January 5, 2010

Published March 31, 2010 